\title{
RELATION OF SOME ANTHROPOMETRIC PARAMETERS OF CHILDREN AGED 13-16 YEARS WITH THEIR EATING HABITS AND PHYSICAL ACTIVITY
}

\author{
Kandela Õun, Monika Übner
}

Pärnu College, University of Tartu, Estonia

\begin{abstract}
People's lifespan is increasing. Therefore, it is necessary to keep the high quality of life. Healthy lifestyle is related to healthy food and must include some physical activities. The aim of the study was to analyse how students' (aged 13-16 years) eating habits and physical activity are related to the height-weight classes. They were administered a questionnaire that asked for information about the frequency of eating different food groups. Based on the 5 SD height-weight classification devised by the Centre for Physical Anthropology at the University of Tartu, the subjects were divided into five classes. Boys were more often overweight than girls. Most of the normal-weight boys and girls in the present study ate breakfast and had a school lunch. Their diet was sufficiently healthy, but included too many sweets and beverages with sugar. According to the heightweight classification, the group of leptomorphs was the largest $-27.8 \%$ of girls and $29.6 \%$ of boys. Pycnomorphs and large respondents did not like to eat in the morning but ate extra food at school. Although pycnomorphs were heavy, they were physically more active than others.
\end{abstract}

Keywords: height-weight classification, eating habits, physical activity

\section{INTRODUCTION}

Nowadays, people's lifespan is increasing, and therefore knowledge of healthy lifestyle needs to be brought to younger persons. Young people aged between 11 and 15 years face many physical, emotional and social changes. These years may influence their health and development of health-related behaviour [4]. 
Health behaviour in school-aged children (HBSC), a WHO collaborative cross-national study, collects data on 11-, 13- and 15-year-old boys' and girls' health and well-being, social environments and health behaviour in every four years [4]. Boys tend to be more overweight than girls, and the number of overweight children is growing after each following study. 11-year-old children were more overweight than 15-year-olds [1].

Overweight and obesity carry serious health consequences that can last into adulthood [21], including metabolic disturbances that increase the risk of cardiovascular diseases and diabetes $[11,15,20]$. HBSC findings indicate that overweight young people are more likely to skip breakfast and are physically less active $[10,16]$. Overweight and obesity have become more prevalent in industrialized countries [19], and concern about body weight and dissatisfaction with it have increased [2]. Girls are particularly conscious of their bodies [4].

In the HBCS 2009/2010 study [4], 41\% of 13-year-old Estonian girls and $32 \%$ boys of the same age thought that they were too fat. With these numbers, Estonia was in the $9^{\text {th }}$ place among 41 countries. Among the 15 -year-olds, the same percentages were 39\% (girls) and 21\% (boys), and the place among the countries was the $24^{\text {th }}$. Estonian 15-year-old girls were similar to Latvians and Lithuanians. The Baltic countries had smaller values than the Scandinavian and Western European countries but higher numbers than Russia and the Eastern European countries. Boys also reported themselves as "too fat". These percentages were similar in the Baltic countries, Russia and the Eastern European countries but lower than in the Scandinavian and Western European countries. $13 \%$ of 13 -year-old and $19 \%$ of 15 -year-old girls were on diet or did something else to lose weight, but boys' percentage was lower, accordingly $8 \%$ and $9 \%$.

In the HBCS study [1], the children's weight and height values were selfreported. To evaluate the overweight, the body mass index (BMI) was calculated. Children's BMI changes with age, falling during the preschool years and then rising again during adolescence. For this reason, child BMI needs to use age-related reference curves, which have been produced for a number of countries [17]. These curves give specific cut-off points for BMI in childhood and children can be divided as underweight, normal-weight and overweight $[3,8]$. Danubio et al [5] have observed that BMI calculated from self-reported and measured parameters does not statistically differ. Respondents underreport their weight by $2-4 \mathrm{~kg}$ and overreport their height by $2-3 \mathrm{~cm}$. The researchers 
believe that self-reported data should be corrected before analysis. Drake et al [6] also found that BMI based on self-reported data was normally underestimated by girls and overweight or obese adolescents. In the Estonian HBCS study [1], it was observed that in the case of measured parameters the number of overweight children was $4 \%$ larger.

Kaarma et al [12] have found that BMI is not correlated with body height but is correlated with indicators of body fat content and also with body weight. Therefore, it cannot replace the analysis of different body types [18]. BMI is a whole body characteristic and not only related to body fat content. For classification of body measurements, height and weight are more preferable. BMI is a valuable addition to height-weight classes [12].

The Centre for Physical Anthropology at the University of Tartu has introduced a height-weight classification which consists of five classes: small - small height, small weight; medium - medium height, medium weight; large - big height, big weight; pycnomorphs - big weight, small height; leptomorphs small weight, big height [13].

There are no universal methods for comparing a person's body build and the amount of food consumed. Peterson et al [18] have revealed that anthropometric data show statistically significant correlation with nutrition. Therefore, the body composition is related to the amount of consumed food. For example, the consumption of energy and main nutrients in the class of pycnomorphs is lower than in the class of leptomorphs in total amount as well as per $1 \mathrm{~kg}$ of body weight. In the class of pycnomorphs, body fat content is significantly higher and body density significantly lower than in the class of leptomorphs.

It is informative to find some relations with different height-weight classifications and respondents' behaviour. For that purpose a classification with BMI cut-off points and the height-weight SD classification were used.

\section{MATERIAL AND METHODS}

All the subjects had participated in the studies of healthy eating habits and physical activity among the students from two Pärnu schools [7, 14]. The data were collected in an unidentifiable form; no sensitive personal data were recorded. Anonymous, specially designed questionnaires were used to collect the following information: personal details, eating habits during the day, understanding about healthy food, favourite food, frequency of eating some food, 
type and frequency of sport activities. The questionnaires were administered in the 2012/2013 academic year to the students (aged 13-16 years) in Pärnu Rääma Basic School and Pärnu Russian Secondary School. The participation in the research was voluntary. The students' height and weight were not measured in situ; these data were self-reported.

The body mass index (BMI) was calculated using the following standard equation: BMI $\left(\mathrm{kg} / \mathrm{m}^{2}\right)=$ weight $(\mathrm{kg}) /$ height $\left(\mathrm{m}^{2}\right)$. By the BMI, children at the age of 13-16 years can be divided as underweight, normal-weight and overweight. Underweight criteria by Grünberg et al [8] and overweight criteria by Cole et al [3] are presented in Table 1.

Table 1. Cut-off points for BMl for underweight and overweight by gender and age

\begin{tabular}{ccc|cc}
\hline \multirow{2}{*}{ Age, years } & \multicolumn{2}{c}{ Underweight, $\mathbf{~ k g} / \mathbf{m}^{\mathbf{2}}$} & \multicolumn{2}{c}{ Overweight, $\mathbf{~ k g} / \mathbf{m}^{\mathbf{2}}$} \\
\cline { 2 - 5 } & Boys & Girls & Boys & Girls \\
\hline 13 & 15.5 & 15.3 & 21.9 & 22.6 \\
\hline 14 & 16.1 & 16.1 & 22.6 & 23.3 \\
\hline 15 & 16.7 & 17.0 & 23.3 & 23.9 \\
\hline 16 & 17.1 & 17.6 & 23.9 & 24.4 \\
\hline
\end{tabular}

Statistical analysis was performed using the SPSS program. First, the mean values $(\bar{x}$, standard deviations (SD) and minimum and maximum values of all anthropometric values were found. Based on the means and standard deviations of height and weight, the students were divided in five classes using the height-weight SD classification, which was introduced by the Centre for Physical Anthropology at the University of Tartu [18].

\section{RESULTS AND DISCUSSION}

The age of respondents varied from 13 to 16 years. The total number of participants was $142-71$ girls and 71 boys. The means and standard deviations of height and weight by gender and age are shown in Table 2 . 


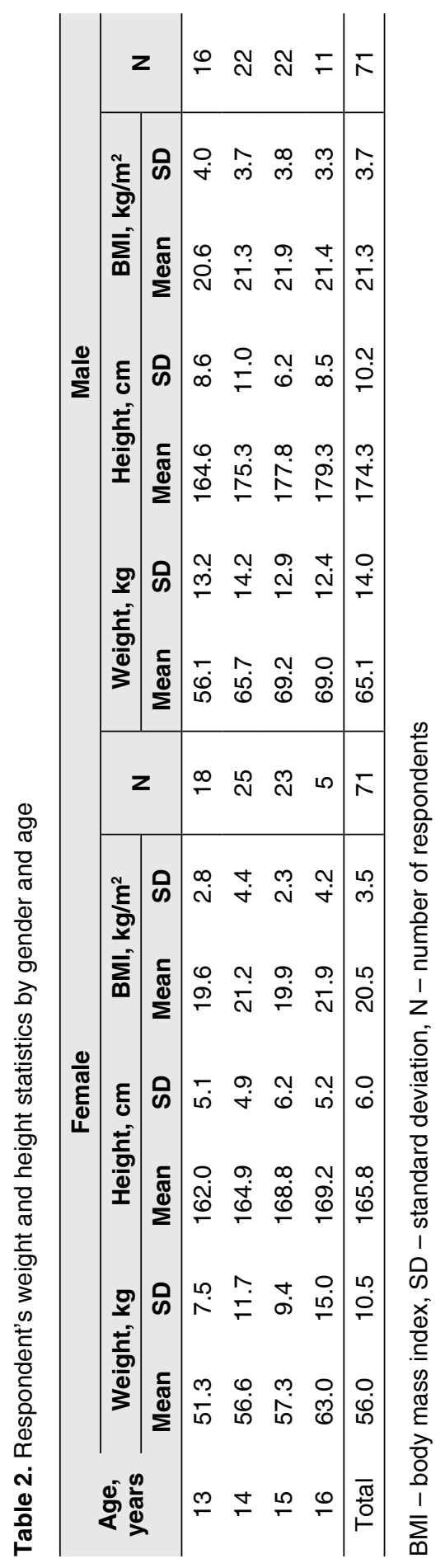


In the HBSC study [4], $13 \%$ of girls and $18 \%$ of boys among 13 -year-old Estonian respondents reported that they were overweight or obese according to BMI. Among the 15-year-olds, these numbers were $9 \%$ and $16 \%$ accordingly. In the present study, the 13-year-old girls' percentage was lower, but that of boys' of the same age - much higher. For 15-year-old girls, overweight or obese respondents' percentage was same as in the HBSC study, but the percentage for boys of the same age was significantly higher (Figure 1). Comparing the findings with a 1997-1999 study [9], we found that 15-year-old girls' mean BMI was lower than in the previous study. 15-year-old boys' BMI was $20.2 \mathrm{~kg} / \mathrm{m}^{2}$ in the previous study but had increased $8.4 \%$ in this study (Table 2).

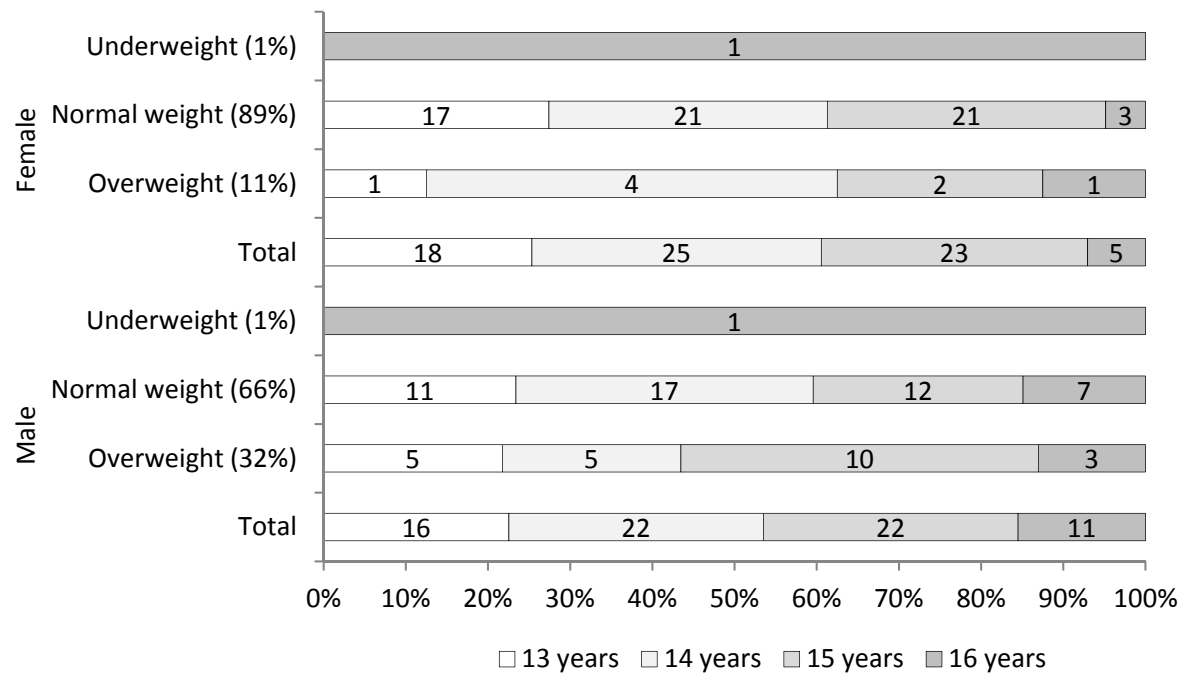

Figure 1. Respondents' gender and weight classification distribution by Grünberg et al [8] (underweight) and Cole et al [3] (overweight)

As the HBCS 2009/2010 study [4] findings show, the prevalence of overweight and obesity varies across regions. No clear age pattern has been identified, but gender differences are apparent. In most countries, boys tend to be more overweight than girls. Reasons for that might include that girls' eating habits are healthier, boys eat more fast foods [22], and parents are less likely to encourage boys to control their weight.

Eating habits of Pärnu school students are given in the Table 3. Based on the available data, only normal and overweight respondents were compared. There were only two underweight respondents, and their data were not used. Only 
normal-weight students' answers could be analysed by age, as there were not enough underweight or overweight respondents for comparison.

Table 3. 13-16 years students who answered "yes" to various behaviour questions

\begin{tabular}{|c|c|c|c|c|}
\hline \multirow{2}{*}{$\begin{array}{c}\text { Respondents' } \\
\text { behaviour }\end{array}$} & \multicolumn{2}{|c|}{ Female } & \multicolumn{2}{|c|}{ Male } \\
\hline & $\begin{array}{c}\text { Normal weight } \\
(\mathrm{N}=63)\end{array}$ & $\begin{array}{c}\text { Overweight } \\
(\mathrm{N}=8)\end{array}$ & $\begin{array}{c}\text { Normal weight } \\
(\mathrm{N}=47)\end{array}$ & $\begin{array}{l}\text { Overweight } \\
(\mathrm{N}=23)\end{array}$ \\
\hline Breakfast consumption & $92 \%$ & $75 \%$ & $98 \%$ & $78 \%$ \\
\hline Importance of breakfast & $87 \%$ & $63 \%$ & $91 \%$ & $74 \%$ \\
\hline Eating school lunch & $73 \%$ & $88 \%$ & $87 \%$ & $74 \%$ \\
\hline Is school lunch healthy? & $67 \%$ & $50 \%$ & $79 \%$ & $70 \%$ \\
\hline Eating snacks in school & $49 \%$ & $50 \%$ & $36 \%$ & $43 \%$ \\
\hline $\begin{array}{l}\text { Info about healthy diet } \\
\text { comes from } \\
\text { school }\end{array}$ & $13 \%$ & $13 \%$ & $32 \%$ & $9 \%$ \\
\hline parents & $33 \%$ & $38 \%$ & $38 \%$ & $22 \%$ \\
\hline the Internet & $30 \%$ & $25 \%$ & $17 \%$ & $22 \%$ \\
\hline magazines & $13 \%$ & $25 \%$ & $13 \%$ & $9 \%$ \\
\hline Engaged in sports & $70 \%$ & $75 \%$ & $85 \%$ & $87 \%$ \\
\hline
\end{tabular}

By the HBSC 2009/2010 study [4], 60\% of 13-year-old girls (in the present study $-89 \%$ ) and $64 \%$ of boys (present study - 100\%) eat breakfast. From 15-year-old girls, 58\% preferred to eat in the morning (present study $89 \%$ ) and from boys $68 \%$ (present study 96\%). In the present study, normal-weight boys and girls ate breakfast more often than overweight respondents, considering it the most important meal in the day. Frequency of eating breakfast increased with the girls' age. For boys, it also increased with age up to $100 \%$ at the age of 15 years but then decreased to $86 \%$. Breakfast was more important for younger girls whose acceptance rate was over $80 \%$, but in the 16 -year-old girls, it was only $66 \%$. Younger boys also accepted the importance of eating breakfast, but only $75 \%$ of 15 -year-old boys agreed to it. The respondents generally ate sandwiches for breakfast (Figure 2), and the boys did it more often. In the second place, there were dry cereals. Overweight girls did not like to eat porridge in the morning. They ate more yoghurt and dry cereals than sandwiches. 


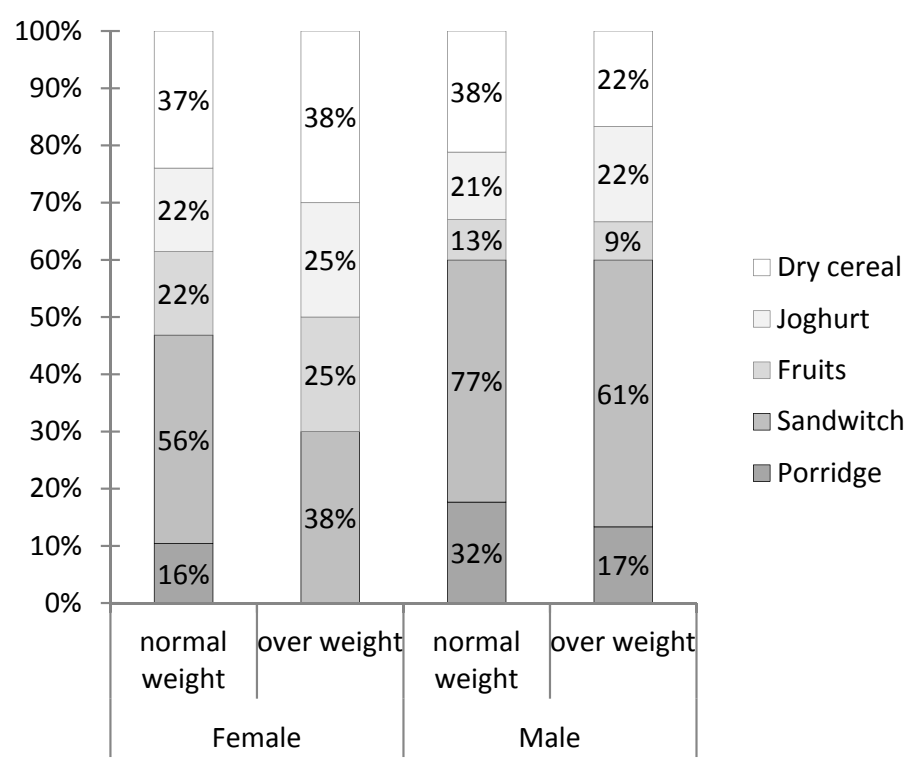

Figure 2.

Student's preferences for breakfast

Most respondents ate lunch in school, and more than half considered it healthy (Table 3). Not eating school lunch was more common in young students because it tastes differently from home food. Both genders evaluated school food as satisfactory. Overweight girls and normal-weight boys evaluated lunch somewhat better, but the difference was not statistically relevant. Half of the girls ate snacks in school, but less than half of the boys did. According to the instructions [23], children and adolescent should eat four times per day: breakfast, lunch, afternoon snack and dinner.

Information about healthy diet was given by parents or could be found on the internet. Girls liked to use more internet information. Overweight girls got information mostly from parents, and normal-weight boys were more active in getting information than overweight boys.

Boys practised sports more often than girls did, and overweight students were physically more active by a few per cent than normal-weight children (Table 3). Girls practised sports 1-2 or 3-4 times in week (25\%), but boys mostly 3-4 times per week (32\%). Overweight boys were physically more active (43\%) than normal-weight boys. More boys trained every day (27\%) than girls (8\%) did. After school, $21 \%$ of normal-weight girls took a walk, which lasted for 28.3 minutes on the average. From overweight girls, $50 \%$ took a walk, but it lasted for only 6.3 minutes. $43 \%$ of boys also liked walking after school; 
overweight boys did it for 42.6 minutes and normal-weight boys for $26.5 \mathrm{~min}$ utes. Girls spent 1-2 hours on sedentary activities daily (19\% of normal-weight girls, 38\% of overweight girls). Normal-weight boys spent 3-4 hours on that (19\%) and overweight boys 1-2 hours (26\%). This means that the subjects of the study were physically active enough every day. According to the instructions [23], all adolescents should be physically active at least one hour every day.

Analysis of consumption frequency of different foods by normal-weight boys and girls is given in Figure 3. Normal-weight boys consumed rye bread, milk and fruits every day. Girls used more fruits, juice and milk products every day. Boys ate more pasta, fish and sausage once a week, but girls liked more pasta, meat and vegetables. Chips and nuts were eaten rarely by both boys and girls.

The daily diet must contain a lot of different minerals and vitamins. Fruit and vegetables also contain fibre that is useful for digestion [1]. Children like to eat fruit, but more boys than girls ate vegetables every day. Milk contains proteins, calcium, phosphorus, potassium, magnesium and vitamins A, B and D. Milk is useful for bones, fingernails and hair [1]. More than half of normalweight respondents liked to drink milk every day, and boys liked it more. Fish contains useful fatty acids and vitamin $\mathrm{D}$, and dieticians suggest eating fish twice a week [1]. In the present study, $67 \%$ of boys and 55\% of girls ate fish at least once a week. Sweets and beverages with sugar contain a lot of extra energy. Overusing them by children may result in obesity [1]. In the present study, half of the respondents used sweets and beverages with sugar every day. Boys had higher frequency values than girls did. Long-time overuse of energy may raise the body weight of children who are now in normal weight. Chips should not be eaten more often than once a month because they contain too much fat and salt [1]. That suggestion was followed by half of the boys and girls.

The 5 SD height-weight classification [18] was used to divide the respondent's height and weight into the three classes and then five SD classes were formed (Table 4). In the present study, the percentage of leptomorphs was the highest in both genders $-27.8 \%$ of girls and $29.6 \%$ of boys. The percentage of pycnomorphs was the lowest $-13.9 \%$ of girls and $12.7 \%$ of boys. 
Relation of some anthropometric parameters of children aged 13-16 years ... | 283
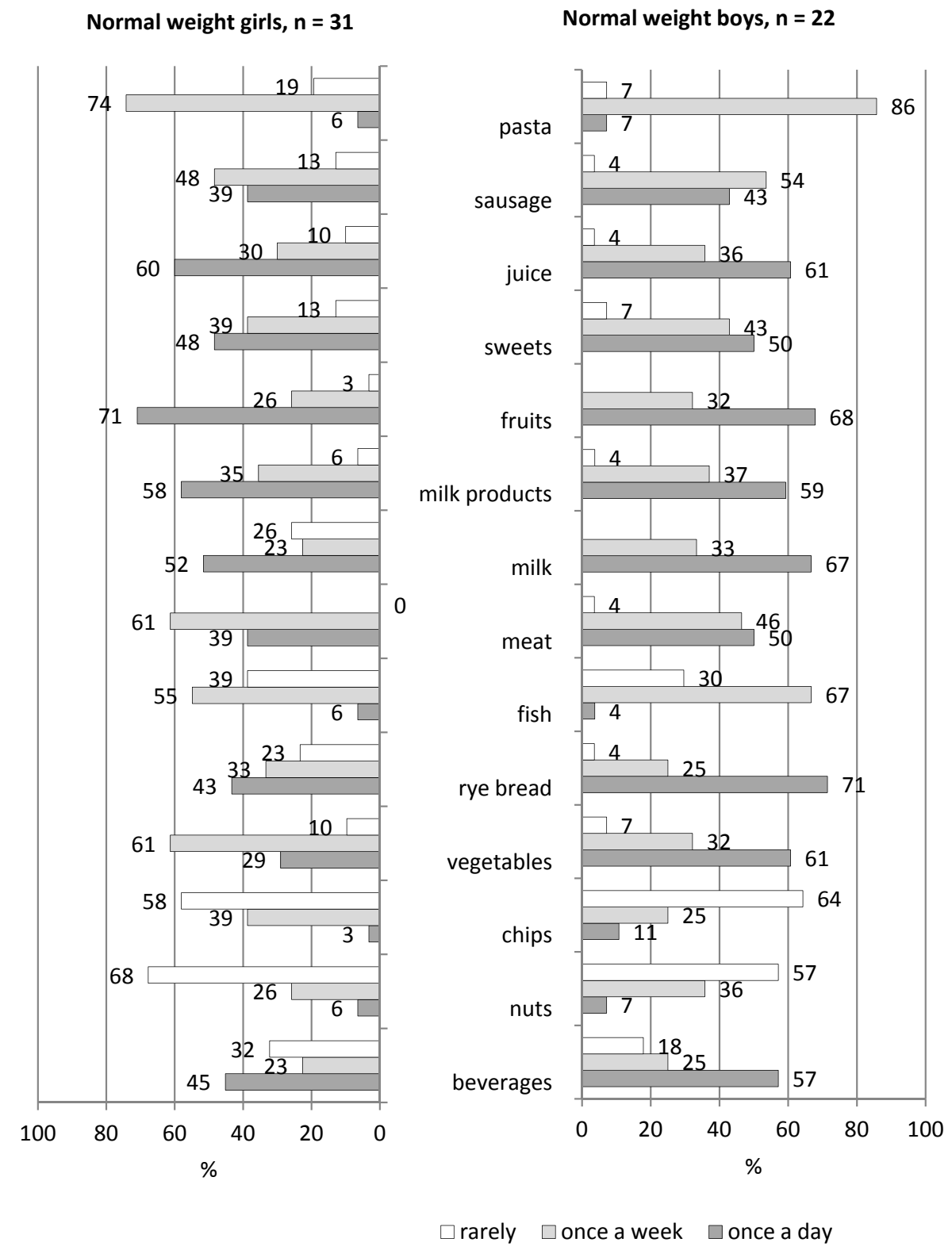

Figure 3. Consumption frequency (\%) of different foods by normal-weight boys and girls 
Table 4. Weight and height classification by gender

\begin{tabular}{|c|c|c|c|c|c|c|}
\hline \multirow{2}{*}{ Gender } & \multirow{2}{*}{$\begin{array}{l}\text { Height } \\
\text { class }\end{array}$} & & \multicolumn{3}{|c|}{ Weight class } & \multirow{2}{*}{ Total } \\
\hline & & & Light & Medium & Heavy & \\
\hline \multirow[t]{4}{*}{ Female } & Short & $\begin{array}{l}\text { Count } \\
\% \text { of total }\end{array}$ & $\begin{array}{r}16 \\
22.2 \%\end{array}$ & $\begin{array}{r}4 \\
5.6 \%\end{array}$ & $\begin{array}{r}1 \\
1.4 \%\end{array}$ & $\begin{array}{r}21 \\
29.2 \%\end{array}$ \\
\hline & Medium & $\begin{array}{l}\text { Count } \\
\% \text { of total }\end{array}$ & $\begin{array}{r}10 \\
13.9 \%\end{array}$ & $\begin{array}{r}13 \\
18.1 \%\end{array}$ & $\begin{array}{r}5 \\
6.9 \%\end{array}$ & $\begin{array}{r}28 \\
38.9 \%\end{array}$ \\
\hline & Tall & $\begin{array}{l}\text { Count } \\
\% \text { of total }\end{array}$ & $\begin{array}{r}1 \\
1.4 \%\end{array}$ & $\begin{array}{r}9 \\
12.5 \%\end{array}$ & $\begin{array}{r}13 \\
18.1 \%\end{array}$ & $\begin{array}{r}23 \\
31.9 \%\end{array}$ \\
\hline & Total & $\begin{array}{l}\text { Count } \\
\% \text { of total }\end{array}$ & $\begin{array}{r}27 \\
37.5 \%\end{array}$ & $\begin{array}{r}26 \\
36.1 \%\end{array}$ & $\begin{array}{r}19 \\
26.4 \%\end{array}$ & $\begin{array}{r}72 \\
100.0 \%\end{array}$ \\
\hline \multirow[t]{4}{*}{ Male } & Short & $\begin{array}{l}\text { Count } \\
\% \text { of total }\end{array}$ & $\begin{array}{r}13 \\
18.3 \%\end{array}$ & $\begin{array}{r}2 \\
2.8 \%\end{array}$ & $\begin{array}{r}1 \\
1.4 \%\end{array}$ & $\begin{array}{r}16 \\
22.5 \%\end{array}$ \\
\hline & Medium & $\begin{array}{l}\text { Count } \\
\% \text { of total }\end{array}$ & $\begin{array}{r}10 \\
14.1 \%\end{array}$ & $\begin{array}{r}12 \\
16.9 \%\end{array}$ & $\begin{array}{r}6 \\
8.5 \%\end{array}$ & $\begin{array}{r}28 \\
39.4 \%\end{array}$ \\
\hline & Tall & $\begin{array}{l}\text { Count } \\
\% \text { of total }\end{array}$ & $\begin{array}{r}1 \\
1.4 \%\end{array}$ & $\begin{array}{r}10 \\
14.1 \%\end{array}$ & $\begin{array}{r}16 \\
22.5 \%\end{array}$ & $\begin{array}{r}27 \\
38,0 \%\end{array}$ \\
\hline & Total & $\begin{array}{l}\text { Count } \\
\% \text { of total }\end{array}$ & $\begin{array}{r}24 \\
33.8 \%\end{array}$ & $\begin{array}{r}24 \\
33.8 \%\end{array}$ & $\begin{array}{r}23 \\
32.4 \%\end{array}$ & $\begin{array}{r}71 \\
100.0 \%\end{array}$ \\
\hline
\end{tabular}

Small, Medium, Large, Pycnomorphs, Leptomorphs

Analysis of eating and physical activities habits by somatotypes (Table 5) revealed that pycnomorphs and large respondents ate less breakfast. Pycnomorphic girls and big boys did not value breakfast, but they mostly ate lunch in school. Small and pycnomorphic girls did not think that school lunch was healthy, and most of them (73\%) ate some extra food at the school. Pycnomorphic boys thought that the food in school was healthy and did not eat extra food at school. The respondents mostly ate the main course for dinner, but pycnomorphs and leptomorphs boys also liked soup, and small boys ate sandwiches at dinner three times more than small girls. Most (85-92\%) pycnomorphic and medium girls practised sports; the percentages of other groups were much lower - 53-64\%. Boys were more physical active than girls, but big and leptomorphic boys were less active than others. 
Table 5. Eating habits and physical activities by gender and somatotypes

\begin{tabular}{|c|c|c|c|c|c|c|}
\hline \multirow[b]{2}{*}{ Habits } & \multirow[b]{2}{*}{ Gender } & \multicolumn{5}{|c|}{ Somatotype } \\
\hline & & Small & Medium & Large & $\begin{array}{l}\text { Pycno- } \\
\text { morphs }\end{array}$ & $\begin{array}{l}\text { Lepto- } \\
\text { morphs }\end{array}$ \\
\hline Eat breakfast & $\begin{array}{l}\text { Female } \\
\text { Male }\end{array}$ & $\begin{array}{l}100 \% \\
100 \%\end{array}$ & $\begin{array}{c}85 \% \\
100 \%\end{array}$ & $\begin{array}{l}85 \% \\
81 \%\end{array}$ & $\begin{array}{l}82 \% \\
70 \%\end{array}$ & $\begin{array}{c}95 \% \\
100 \%\end{array}$ \\
\hline Breakfast is important & $\begin{array}{l}\text { Female } \\
\text { Male }\end{array}$ & $\begin{array}{c}88 \% \\
100 \%\end{array}$ & $\begin{array}{l}92 \% \\
92 \%\end{array}$ & $\begin{array}{l}100 \% \\
69 \%\end{array}$ & $\begin{array}{l}45 \% \\
80 \%\end{array}$ & $\begin{array}{l}89 \% \\
90 \%\end{array}$ \\
\hline Eat school lunch & $\begin{array}{l}\text { Female } \\
\text { Male }\end{array}$ & $\begin{array}{l}81 \% \\
69 \%\end{array}$ & $\begin{array}{l}69 \% \\
75 \%\end{array}$ & $\begin{array}{l}69 \% \\
75 \%\end{array}$ & $\begin{array}{l}91 \% \\
90 \%\end{array}$ & $\begin{array}{c}68 \% \\
100 \%\end{array}$ \\
\hline $\begin{array}{l}\text { School lunch is } \\
\text { healthy }\end{array}$ & $\begin{array}{l}\text { Female } \\
\text { Male }\end{array}$ & $\begin{array}{l}56 \% \\
77 \%\end{array}$ & $\begin{array}{l}69 \% \\
75 \%\end{array}$ & $\begin{array}{l}62 \% \\
63 \%\end{array}$ & $\begin{array}{l}45 \% \\
90 \%\end{array}$ & $\begin{array}{l}84 \% \\
75 \%\end{array}$ \\
\hline Eat snacks in school & $\begin{array}{l}\text { Female } \\
\text { Male }\end{array}$ & $\begin{array}{l}31 \% \\
31 \% \\
\end{array}$ & $\begin{array}{l}46 \% \\
67 \% \\
\end{array}$ & $\begin{array}{l}54 \% \\
50 \% \\
\end{array}$ & $\begin{array}{l}73 \% \\
20 \% \\
\end{array}$ & $\begin{array}{l}47 \% \\
25 \% \\
\end{array}$ \\
\hline $\begin{array}{l}\text { Preferences for } \\
\text { dinner } \quad \text { Soup }\end{array}$ & $\begin{array}{l}\text { Female } \\
\text { Male }\end{array}$ & $\begin{array}{l}13 \% \\
42 \%\end{array}$ & $\begin{array}{c}0 \% \\
42 \%\end{array}$ & $\begin{array}{l}31 \% \\
19 \%\end{array}$ & $\begin{array}{l}27 \% \\
60 \%\end{array}$ & $\begin{array}{l}21 \% \\
55 \%\end{array}$ \\
\hline Main course & $\begin{array}{l}\text { Female } \\
\text { Male }\end{array}$ & $\begin{array}{l}63 \% \\
67 \%\end{array}$ & $\begin{array}{l}92 \% \\
83 \%\end{array}$ & $\begin{array}{l}77 \% \\
75 \%\end{array}$ & $\begin{array}{l}91 \% \\
50 \%\end{array}$ & $\begin{array}{l}68 \% \\
75 \% \\
\end{array}$ \\
\hline Sandwiches & $\begin{array}{l}\text { Female } \\
\text { Male }\end{array}$ & $\begin{array}{l}13 \% \\
42 \%\end{array}$ & $\begin{array}{c}0 \% \\
17 \%\end{array}$ & $\begin{array}{l}23 \% \\
19 \%\end{array}$ & $\begin{array}{l}18 \% \\
40 \%\end{array}$ & $\begin{array}{l}21 \% \\
30 \%\end{array}$ \\
\hline Practise sports & $\begin{array}{l}\text { Female } \\
\text { Male }\end{array}$ & $\begin{array}{c}63 \% \\
100 \%\end{array}$ & $\begin{array}{l}85 \% \\
92 \%\end{array}$ & $\begin{array}{l}92 \% \\
81 \%\end{array}$ & $\begin{array}{l}64 \% \\
90 \%\end{array}$ & $\begin{array}{l}53 \% \\
75 \%\end{array}$ \\
\hline $\begin{array}{l}\text { Walk to and from } \\
\text { school }\end{array}$ & $\begin{array}{l}\text { Female } \\
\text { Male }\end{array}$ & $\begin{array}{l}69 \% \\
54 \%\end{array}$ & $\begin{array}{l}46 \% \\
42 \%\end{array}$ & $\begin{array}{l}69 \% \\
50 \%\end{array}$ & $\begin{array}{l}45 \% \\
30 \%\end{array}$ & $\begin{array}{l}37 \% \\
40 \%\end{array}$ \\
\hline Walk to bus stop & $\begin{array}{l}\text { Female } \\
\text { Male }\end{array}$ & $\begin{array}{l}19 \% \\
15 \%\end{array}$ & $\begin{array}{l}38 \% \\
42 \%\end{array}$ & $\begin{array}{l}38 \% \\
25 \%\end{array}$ & $\begin{array}{l}36 \% \\
40 \%\end{array}$ & $\begin{array}{l}53 \% \\
50 \%\end{array}$ \\
\hline
\end{tabular}

Somatotypes' behaviour cannot be analysed by age because these groups were too small for proper conclusions.

\section{CONCLUSION}

The analysis of school students' eating habits and physical activity in two Pärnu schools showed that their eating habits are sufficiently healthy. Boys tend to be more overweight. Most of the respondents eat in the morning and eat school lunch. They are satisfied with school food, but some of them do not like the taste. Normal-weight boys and girls eat different food groups every day, but use too many sweets and beverages with sugar. According to the height-weight classification, the largest group was leptomorphs. Pycnomorphs and large respondents do not like to eat the breakfast and eat extra food at school. Pycnomorphs are physically more active than others groups. 


\section{ACKNOWLEDGEMENTS}

We thank Birgit Klein and Aleksei Galkin for permission to use the answers to their questionnaires.

\section{REFERENCES}

1. Aasvee K., Eha M., Härm T., Liiv K., Oja L., Tael M. (2012). Eesti kooliõpilaste tervisekäitumine. 2009/2010. õppeaasta Eesti HBSC uuringu raport (Health behaviour of Estonian school students. Report of the Estonian HBSC study for the 2009/2010 academic year). Tallinn: Tervise Arengu Instituut (in Estonian).

2. Cash T. F., Morrow J. A., Hrabosky J. I., Perry A. A. (2004). How has body image changed? A cross-sectional investigation of college women and men from 1983 to 2001. J Consult Clin Psychol 72, 6, 1081-1089.

3. Cole T. J., Bellizzi M. C., Flegal K. M., Dietzet W. H. (2000). Establishing a standard definition for child overweight and obesity worldwide: international survey. BMJ, 320, 1240-1243.

4. Currie C., Zanotti C., Morgan A., Currie D., de Looze M., Roberts C., Samdal O., Smith O. R. F., Barnekow V. eds. (2012). Social determinants of health and wellbeing among young people: Health Behaviour in School-aged Children (HBSC) study: international report from the 2009/2010 survey. Copenhagen, WHO Regional Office for Europe. Health Policy for Children and Adolescents, No. 6.

5. Danubio M. E., Miranda G., Vinciguerra M. G., Vecchi E., Rufo F. (2008). Comparison of self-reported and measured height and weight: Implications for obesity research among young adults. Econ Hum Biol 6, 181-190.

6. Drake K. M., Longacre M. R., Dalton M. A., Langeloh G., Peterson K. E., Titus L. J., Beach M. L. (2013). Two-method measurement for adolescent obesity epidemiology: reducing the bias in self-report of height and weight. J Adolesc Health, in press.

7. Galkin A. (2013). III kooliastme õpilaste toitumisharjumused ja füüsiline aktiivsus Pärnu Vene Gümnaasiumi ja Pärnu Rääma Põhikooli näitel (Eating habits and physical activity of students of the 3rd school stage on the example of Pärnu Russian Secondary School and Pärnu Rääma Basic School). Tallinna Ülikool, Terviseteaduse ja Spordi Instituut (bachelor thesis, in Estonian).

8. Grünberg H., Adojaan B., Thetloff M. (1998). Kasvamine ja kasvuhäired: metoodiline juhend laste füüsilise arengu hindamiseks (Growth and growth disorders: Methodological instructions for assessment of children's physical development). Tartu: Tartu Ülikool (in Estonian).

9. Harro M. (2002). Eesti koolinoorte tervis ja selle sõltuvus perekonna sotsiaalmajanduslikust olukorrast (Estonian school students' health and its dependence 
on the socio-economic situation of the family). Eesti Arst 81, 216-221 (in Estonian).

10. Haug E., Rasmussen M., Samdal O., Iannotti R., Kelly C., Borraccino A., Vereecken C., Melkevik O., Lazzeri G., Giacchi M., Ercan O., Due P., RavensSieberer U., Currie, C., Morgan A., Ahluwalia N. (2009). Overweight in schoolaged children and its relationship with demographic and lifestyle factors: results from the WHO-collaborative Health Behaviour in School-aged Children (HBSC) study. Int J Public Health 54, Suppl. 2, 167-179.

11. Ho T. F. (2009). Cardiovascular risks associated with obesity in children and adolescents. Ann Acad Med Singapore 38, 1, 48-49.

12. Kaarma H., Peterson J., Kasmel J., Lintsi M., Saluste L., Koskel S., Arend A. (2009). The role of body height, weight and BMI in body build classification. Papers on Anthropology XVIII, 155-173.

13. Kaarma H., Saluste L., Lintsi M., Kasmel J., Veldre G., Tiit E.-M., Koskel S., Arend A. (2008). Height and weight norms for adult Estonian men and women (aged 20-70 years). and ways of somatotyping using a height-weight classification. Papers on Anthropology XVII, 113-130.

14. Klein B. (2013). Pärnu Rääma Põhikooli III kooliastme õpilaste toitumisharjumused (Eating habits of the students of the $3^{\text {rd }}$ school stage at Pärnu Rääma Basic School). Pärnu. (school student research, in Estonian)

15. Lobstein T., Baur L., Uauy R. (2004). Obesity in children and young people: a crisis in public health. Obes Rev 5, Suppl. 1, 4-85.

16. Must A., Tybor D. J. (2005). Physical activity and sedentary behavior: a review of longitudinal studies of weight and adiposity in youth. Int J Obes 29, Suppl. 2, S84-S96.

17. Obesity: preventing and managing the global epidemic: report of a WHO consultation. (2000). World Health Organ Tech Rep Ser 894, 1-253.

18. Peterson J., Kaarma H., Koskel S. (2012). An anthropometric model for nutrition research of Estonian female students. Papers on Anthropology XXI, 201-211.

19. Population-based prevention strategies for childhood obesity: report of a WHO forum and technical meeting, Geneva, 15-17 December 2009. (2010). Geneva, World Health Organization.

20. Reilly J. J., Methven E., McDowell Z. C., Hacking B., Alexander D., Stewart L., Kelnar C. J. H. (2003). Health consequences of obesity. Arch Dis Child 88, 9, 748-752.

21. Singh A. S., Mulder C., Twisk J. W., van Mechelen W., Chinapaw M. J. (2008). Tracking of childhood overweight into adulthood: a systematic review of the literature. Obes Rev 9, 5, 474-488.

22. Sweeting H. N. (2008). Gendered dimensions of obesity in childhood and adolescence. Nutrition Journal 7, 1-14. 
23. Õpilase kehakaal, selle psühholoogilised aspektid ning toitumis- ja liikumisnõustamine: juhend kooli tervishoiutöötajale (School students' body weight, its psychological aspects, counselling on nutrition and exercise: Instructions for school health workers). (2007). Koostajad: Maser M., Akkermann K., Fessai N., Kirss M., Sapatšuk I., Villa I. Tallinn : Eesti Terviseedenduse Ühing (in Estonian).

Address for correspondence:

Kandela Õun

Pärnu College

University of Tartu

E-mail: kandela.oun@ut.ee 